\title{
Antifungal activities of methanol extracts of some medicinal plants against germination and growth of Colletotrichum destructivum O'Gara in culture
}

\author{
DAVID NWAZUO ENYIUKWU*, ANDERSON CHIDI AMADIOHA, CHARLES CHIMEZIE ONONUJU \\ Department of Plant Health Management, Michael Okpara University of Agriculture. Umudike, Km 10 Umuahia-Ikot-Ekpene Road, PMB 7267, \\ Umuahia, Abia State, Nigeria. Tel.: +234-9092309790, ^email: enyidave2003@gmail.com
}

Manuscript received: 8 August 2020. Revision accepted: 23 February 2021.

\begin{abstract}
Enyiukwu DN, Amadioha AC, Ononuju CC. 2021. Antifungal activities of methanol extracts of some medicinal plants against germination and growth of Colletotrichum destructivum O'Gara in culture. Asian J Nat Prod Biochem 19: 25-29. Cowpea is an important grain and leafy vegetable in many tropical locations. Anthracnose caused by Colletotrichum destructivum O'Gara is one of the several factors constraining the economical production of the crop in warm, humid areas. The use of resistant varieties and synthetic pesticides to control the disease in the crop are disadvantaged for the variability of the pathogen, leading to resistant failure of cultivars in many cowpea growing areas; and pesticide residues in the treated crops, which ultimately engender mammalian toxicity, respectively. This study evaluated the effects of Alchornea cordifolia, Tabernaemontana pachysiphon, and Lantana camara as eco-friendly fungicides against the pathogen in culture. The results showed that the extracts inhibited the fungus in a dose-wise manner. At 75 and100\% concentrations, L. camara strongly inhibited the spore germination and radial growth of the fungus better than all concentrations of $T$. pachysiphon and A. cordifolia, whereas A. cordifolia extracts exhibited the lowest inhibition at all concentrations. Generally, the fungitoxicity of benomyl was found higher, inhibiting $90.15 \%$ spore germination and $96.32 \%$ radial growth of the pathogen. However, at $75 \%, 100 \%$ L. camara and $100 \%$ T. pachysiphon, which significantly $(\mathrm{P} \leq 0.05)$ inhibited $(80.02 \%, 84.21 \%$, and $80.91 \%)$ spore germination and $(87.33 \%, 90.87 \%$ and $85 . \%)$ radial growth of the fungus respectively compared well with inhibition effects recorded from benomyl. Therefore, these plants can be used as viable protectants of cowpea against anthracnose $(C$. destructivum) in smallholder farming systems of the humid tropics; to enhance its production and farm economy.
\end{abstract}

Keywords: Anthracnose, Colletotrichum destructivum, cowpea, fungicides, plant extracts

\section{INTRODUCTION}

Cowpea is an integral part of several cuisines consumed in many countries of the tropics and sub-tropics, including South Africa, Nigeria, and some parts of Asia. The leaves, pods, and grains rich in protein and phosphorus are cherished organs of the crop, widely eaten as vegetables or pulses amongst many natives (Nielsen 1997; Enyiukwu et al. 2018a).

Anthracnose, a seed or thrash-borne disease caused by Colletotrichum destructivum O'Gara, is a major biotic challenge to the economical production of the crop in many cowpea growing locations (Adegbite and Amusa 2008; Enyiukwu et al. 2018b). The disease is pan-tropical, reducing grain yield by up to $50 \%$ in susceptible cowpea cultivars. In very severe outbreaks, anthracnose can cause total crop failure (Begum et al. 2007: 2013; Amadioha and Enyiukwu 2019a). Besides, reducing the quality of grain and vegetables due to loss of vital biochemicals also results from attacks of the pathogen on the crop. Recently, we reported a mean loss of major nutrients (protein, lipids, carbohydrate) of $38.29 \%, 28.95 \%, 22.55 \%$, and $18.14 \%$ for the leaves, seeds, husks, and stem, respectively, of infected cowpea 8 weeks after planting; while loss of 11.86 $\% \mathrm{Ca}$ and $13.63 \% \mathrm{P}$ was recorded in the crop grains in storage about the same period (Amadioha and Enyiukwu 2019a, b).

Though good agronomic practices and the use of resistant varieties are invaluable strategies for curbing the disease (Awurum et al. 2001; Enyiukwu and Awurum 2013); however, the use of resistant varieties has the disadvantage of being short-lived due largely to the variability of the anthracnose fungus which could lead to resistance failure in the cultivars (Podila 1993; Enyiukwu et al. 2014). Generally, chemical treatments are effective in arresting the development and spread of the pathogen. Still, such interventions have been trailed by several forms of mammalian toxicities, congenital disabilities, allergies, male sterility, and even death owing to residues of the pesticides in crops and the environment (BMC 1992; Awurum and Enyiukwu 2013). These, amongst other factors, ignited the search for alternatives or at least complements to the synthetic pesticides by scientists (Asawalam and Emosairue 2006; Nwaogu and Wokocha 2018).

Several biological activities have been reported about many families of tropical higher plants against a wide array of microorganisms, such as viruses, bacteria, and fungi, which are pathogenic to humans and plants (Enyiukwu et al. 2014; Mgbeahuruike et al. 2017, 2018; Enyiukwu 2019). Interestingly Alchornea cordifolia, Tabernaemontana pachysiphon, and Lantana camara have long been used in 
ethnobotany and phytotherapy of many cultures. Recent antimicrobial evaluations of these plants on storage pathogens showed that they inhibited Botrydiplodia fumigatus, Aspergillus fumigatus, and Penicillium notatum (Amienyo and Ataga, 2007; Naz and Bato, 2013; Duru et al. 2015). However, the antifungal activities of extracts or compounds derived from these medicinal plants against Colletotrichum destructivum are scarce. Therefore, the purpose of this study is to evaluate the inhibitory effects of methanol extracts of Alchornea cordifolia, Tabernaemontana pachysiphon, and Lantana camara in culture against $C$. destructivum O'Gara and causing anthracnose of cowpea in Nigeria.

\section{MATERIALS AND METHODS}

\section{Collection and preparation of plant materials}

Leaves of the plant materials [Alchornea cordifolia (Schumach. and Thonn.) Mull. Arg., Lantana camara Linn. and Tabernaemontana pachysiphon Stapf] were obtained from the University community and Umudike in Abia State. The leaves were washed thoroughly in tap water, rinsed with sterile distilled water, and air-dried on the laboratory bench for 20 days. After that, they were milled separately into a fine powder using a hand milling machine (Model Corona Lavesh 250) to obtain $300 \mathrm{~g}$ of each sample which was stored separately in air-tight bottles. Each powder was weighed out separately in $25,50,75$, and 100 $\mathrm{g}$ in different $250 \mathrm{~mL}$ conical flasks, to which $100 \mathrm{~mL}$ of $30 \%$ methanol was added, and the flask was closed with foiled stoppers. They were allowed to stand for $2 \mathrm{~h}$. They were then strained separately through 4-folds of sterile cheesecloth into different $200 \mathrm{~mL}$ beakers to obtain the respective methanol filtrates of $25,50,75$, and $100 \%$ concentrations of the test samples (Amadioha 2003).

\section{Preparation of culture medium (PDA)}

About 39.5 grams of potato dextrose agar (PDA) (Oxoid $^{\mathrm{TM}}$ ThermoScientific Product, England, UK) was dissolved in $1000 \mathrm{~mL}$ of sterile distilled water in a 1000 $\mathrm{mL}$ conical flask to which 4 drops of lactic acid were added and then stirred vigorously before closing the flask with foiled cotton wool and autoclaving at 15 pounds per square inch (Psi) $\left(152 \mathrm{cmHg}, 120^{\circ} \mathrm{C}\right)$ pressure for 15 minutes.

\section{Isolation and identification of the causal organism}

Bits of cowpea (Vigna unguiculata L. Walp.) (Var. IAR 48 ) pods with typical anthracnose symptoms (12 mm) were sterilized in $70 \%$ ethanol for $1 \mathrm{~min}$ and then washed several times with $50 \mathrm{~mL}$ of sterile distilled water. The tissues were plated in blotter paper and incubated for 7 days at $27^{\circ} \mathrm{C}$. The mycelial growth from the plated cowpea tissues was subcultured on PDA slants.

The color and colony characteristics of the isolate were observed under the microscope and recorded. Slides were prepared, fixed, mounted, and examined under a low/high power Olympus digital compound microscope fitted with the software Scopevision version 9.0. The morphological characteristics of the conidia and structures of the fungus captured in photographs were used to compare and confirm its identity concerning the illustrated species by Shen et al. (2001), Damm et al. (2014), and monographs of the International Mycological Institute (IMI 1995).

Pathogenicity test: A spore suspension of the fungal isolate $\left(1 \times 10^{5}\right.$ spores $/ \mathrm{mL}$ of distilled water) was sprayed with a sterile syringe on healthy (uninfected) 7-day-old cowpea seedlings. The seedlings inoculated with the isolate showed severe infection of anthracnose disease with watersoaked lesions covered with black acervuli all over the hypocotyls after 3 days of inoculation. Severely affected seedlings became weak, deteriorated, and eventually died. Control seedlings were sprayed with sterile distilled water. They grew well without black or tan-colored, water-soaked lesions. The isolate caused typical symptoms in the cowpea plant, similar to the original isolate, which confirmed it as a pathogen. The test fungus was re-isolated from the diseased seedlings, re-examined, and confirmed identical with the previously isolated and inoculated isolate.

\section{In vitro experiment}

Preparation of spore suspension

The spores of Colletotrichum destructivum O'Gara were collected from 10-day-old culture-agar stock in Petri dishes by lifting $60 \mathrm{~cm}^{2}$ pieces into a beaker containing $200 \mathrm{~mL}$ of sterile distilled water. This was sieved through 4-folds of sterile cheesecloth to remove agar and mycelia fragments, and the filtrate was centrifuged for 10 minutes. The spore suspension was then adjusted to $10^{5}$ spores $/ \mathrm{mL}$ of sterile distilled water using a hemocytometer counting slide.

\section{Effect of plant extracts on spore germination of \\ Colletotrichum destructivum}

The method of Amadioha (2003) was adopted to evaluate the effect of the extracts of the test plants on the germination of the spores of C. destructivum. A disc ( $3 \mathrm{~mm}$ ) of the fungus was placed in $3 \mathrm{~mL}$ of the different concentrations $(25,50,75$, and $100 \%)$ of the crude methanol extracts of the different plants or benomyl (as a placebo) contained in different test tubes. The test tubes and their contents were then centrifuged for 10 minutes. After that, the resulting supernatants were then filtered through 4-folds of cheesecloth. A drop $(0.05 \mathrm{~mL})$ of the different concentrations was placed separately on 3 sterile slides and incubated for spore germination at $27^{\circ} \mathrm{C}$ for $24 \mathrm{~h}$ in a humid chamber. The controls were maintained similarly but consisted of sterile water or benomyl. Further spore germination was stopped by adding one drop of lactophenol in cotton blue to each slide preparation. The effect of the tissue extracts from the plant materials on the germination of the test fungus spores was determined by examining 100 randomly selected pathogen spores under a microscope. Records of the number of germinated spores for each treatment/replicate were taken and then used to determine the percentage inhibition of spore germination of the pathogen compared to the controls using the formula by Amadioha (2003) as:

$$
\% \text { Inhibition of spore germination }=\mathrm{gc}-\mathrm{gt} \times 100
$$


Where:

$\mathrm{gc}=$ average number of germinated spores of the test fungus with control

gt $=$ average number of germinated spores of the test fungus with treatment

\section{Effect of the extracts on radial growth of Colletotrichum destructivum}

One (1) $\mathrm{mL}$ of different concentrations $(25,50,75$, and $100 \%)$ of the crude methanol extracts of the plant materials were smeared separately on the surface of solidified PDA by gentle swirling motion (Amadioha 2003). A disc (3 mm) of the 10-day-old culture of the pathogenic fungus was transferred to the Petri dishes center, which had been marked underneath with two perpendicular lines intersecting at the center. The dishes were covered and incubated at $27^{\circ} \mathrm{C}$ for 7 days. The controls were maintained similarly but with sterile distilled water or benomyl mixed with the PDA in the dishes. The radial growth of the pathogen was measured along the perpendicular lines with a meter rule 7 days after incubation.

The fungitoxicity of the extract was determined as a percentage of mycelial growth inhibited and calculated by the formula as adopted by Amadioha (2003; Amadioha et al. 2019):

$\%$ Growth inhibition $=\frac{\mathrm{dc}-\mathrm{dt}}{\mathrm{dc}} \times 100$

Where:

$\mathrm{dc}=$ average diameter of the fungal colony with control $\mathrm{dt}=$ average diameter of the fungal colony with treatment.

\section{Data analysis}

The experiments were conducted in Completely Randomized Design (CRD), consisting of 14 treatments replicated 3 times. The whole experiment was repeated twice. Data collected from the study were analyzed by analysis of variance (ANOVA) using the general linear model procedure in Genstat Release (Windows/PC Vista, version 12.10) at a significant level of $5 \%$. Means were separated and compared using Fisher's LSD at the probability of 0.05 .

\section{RESULTS AND DISCUSSION}

\section{Results}

The result of in vitro effect of the crude methanol extracts of the test plant materials and benomyl on the spore germination and radial growth of the fungus is presented in Table 1. The result showed that both the crude methanol extracts and benomyl significantly $(\mathrm{P} \leq 0.05)$ inhibited the spore germination and radial growth of the fungus in the culture. It also revealed that crude extracts of the test plants varied in their inhibitory activities against the fungus. Among the three plants, L. camara at $100 \%$ concentration was the most toxic to the fungus and exhibited $84.21 \%$ and $90.87 \%$ inhibition of spore germination and radial growth of the pathogen. $T$. pachysiphon at $100 \%$ concentration exhibited $80.91 \%$ and $85.14 \%$ inhibition for spore germination and radial growth of the pathogen, respectively, while A. cordifolia was the lowest inhibition effect on the test parameters of the fungus at all concentrations.

Similarly, at $75 \%$ concentration, L. camara inhibited the germination of spores of the pathogen by $80.02 \%$ and impeded radial growth of the fungus by $89.33 \%$. In general, the sensitivity profile of the pathogen to the toxicants at $75 \%$ concentration was $L$. camara $>T$. pachysiphon $>A$. cordifolia. However, the fungi toxic activities of the plant extracts were not as effective as benomyl which inhibited spore germination and radial growth of the fungus by $90.15 \%$ and $96.32 \%$, respectively. However, results of the inhibition effects obtained for L. camara at $75 \%$ and $100 \%$ dosages and $T$. pachysiphon at $100 \%$ concentration of incorporation in the media (Table 1) compared statistically $(\mathrm{P} \leq 0.05)$ well with those of benomyl for the same parameters respectively.

\section{Discussion}

Incorporation of methanol extracts of L. camara into the culture medium in this study strongly inhibited spore germination and significantly $(\mathrm{P} \leq 0.05)$ retarded radial growth of $C$. destructivum better than extracts of $T$. pachysiphon and A. cordifolia (Table 1).

Table 1: Fungioxic effect of methanol extracts of test plants and benomyl on the spore germination and radial growth of Colletotrichum destructivum

\begin{tabular}{lcc}
\hline \multirow{2}{*}{ Treatment } & \multicolumn{2}{c}{$\begin{array}{c}\text { Percentage growth } \\
\text { inhibition }\end{array}$} \\
\cline { 2 - 3 } & $\begin{array}{c}\text { Spore } \\
\text { germination* }\end{array}$ & $\begin{array}{c}\text { Radial } \\
\text { growth** }\end{array}$ \\
\hline Alchornea cordifolia & & \\
100\% & 51.23 & 59.08 \\
$75 \%$ & 47.08 & 51.12 \\
$50 \%$ & 41.20 & 48.07 \\
$25 \%$ & 41.09 & 45.55 \\
Tabernaemontana pachysiphon & & \\
100\% & 80.91 & 85.14 \\
$75 \%$ & 63.45 & 69.01 \\
$50 \%$ & 58.33 & 64.33 \\
25\% & 50.13 & 60.04 \\
Lantana camara & & \\
100\% & 84.21 & 90.87 \\
$75 \%$ & 80.02 & 87.33 \\
50\% & 77.46 & 84.50 \\
25\% & 70.10 & 79.89 \\
& & \\
Fungicide (Benomyl) & 90.15. & 96.32 \\
Control (Methanol) & 0.00 & 0.00 \\
LSD (0.05) & $\mathbf{9 . 3 1 5}$ & $\mathbf{1 1 . 0 1 8}$ \\
\hline
\end{tabular}

Note: Data are means of values from 2 separate experiments replicated 3 times 
Several Colletotrichum species. caused anthracnose disease in cowpea, which has been effectively controlled by using fungicides of plant origin. Xylopia aethiopica, Azadirachta indica, Cymbopogon citratus, and Piper nigrum were reported to inhibit the growth of Colletotrichum lindemuthianum in vitro and in vivo (Amadioha and Obi 1998; Amadioha 2003). In a trial, extracts of Piper guineense substantially inhibited spore germination of $C$. destructivum (Enyiukwu and Awurum 2011).

Similarly, Monodora myristica, Argemone mexicana, Tephrosia purpurea, Diodia scandens, and Cyathula prostrata were reported to retard the development of $C$. destructivum in culture (Akinbode and Ikotun 2008; Obi 2011; Ogu and Owoeye 2013; Obi and Barriusa-Vargas 2014). In all these evaluations, the botanicals acted by inhibiting spore germination and retarding the pathogenic organisms' radial growth and mycelial biomass (Amadioha, 2003; Mukherjee et al. 2011; Ogu and Owoeye, 2013; Obi and Barriusa-Vargas 2014). Across concentrations in this study, extracts of A. cordifolia, T. pachysiphon, and $L$. camara showed moderate to strong inhibition of both spore germination and radial growth of $C$. destructivum, thereby corroborating the reports of findings of the other workers above.

However, in this study, the antifungal activity of the test plants against the spore germination and radial growth of $C$. destructivum were inferior to benomyl and did not confirm the report of Costa da Silva et al. (2012; 2014), where the extract of Hyptis marrubioides was significantly superior to carbendazim in inhibiting the spore germination and radial growth of $C$. truncatum and Phakopsora pachyrhizi causing anthracnose disease and rust of soybean respectively. The pesticide activity of botanicals is based on the type of active chemical principle and the amounts of functional groups involved (Enyiukwu and Awurum 2012). Therefore, the fewer fungi toxic efficacy of test plant extracts in this study may indicate that their active ingredients differ widely in structure, type, and amount of substituent functional chemical groups from benomyl.

In general, it was noted that the fungi toxic activity of the tissue extracts increased with the concentration of test extracts (Table 1). This also agrees with the reports of other investigators (Suleiman and Emua 2009). The fungitoxicity profile of the concentrations of plant extracts on the test fungus in this study was $100 \%>75 \%>50 \%>25 \%$. The antifungal activity of botanicals was influenced by the concentration or amount of the active chemical compounds in the medium, which in turn is dependent on the compound's solubility in the extraction solvent (Amadioha 2003). Therefore, the differential toxicity of the botanical extracts against the pathogen may have been influenced by the solubility of the active principles in methanol. The chemical compounds of $L$. camara were perhaps more soluble than T. pachysiphon and A. cordifolia.

Enyiukwu (2017) noted the presence of Dodecanoic acid (commonly called lauric acid) in L. camara (42.57 $\%)$ ), T. pachysiphon (29.69\%), and A. cordifolia (15.87 $\%)$. Dodecanoic acid (1,2,3-propanetryl ester) is reported to possess stronger antimicrobial activities than the other fatty metabolites (Nakatsuji et al. 1995; Rajeswari et al. 2012; Omotosho et al. 2014; Axe 2017; COC 2017). Hence, a higher amount of Dodecanoic acid (1,2,3-propanetryl ester) found in L. camara and T. pachysiphon may be the reason for high fungi toxic activities against $C$. destructivum over A. cordifolia.

Therefore, these plant extracts can be used as possible fungicides in smallholder farming systems to protect cowpeas from anthracnose caused by $C$. destructivum O'Gara; and hence improve the productivity of the crop and food security in the sub-region

\section{REFERENCES}

Adegbite AA, Amusa AN. 2008. The major economic field diseases of cowpea in the humid agro-ecologies of South-Western Nigeria. Afr J Biotech 7 (25): 4705-4712.

Akinbode AO, Ikotun T. 2008b. Efficacy of certain plant extracts against seed-borne infection of Colletotrichum destructivum on cowpea (Vigna unguiculata). Afr J Biotechnol 7 (20): 3683-3685.

Amadioha AC, Enyiukwu DN. 2019. Biochemical composition of seed and husk of cowpea (Vigna unguiculata L. Walp.) infected by Colletotrichum destructivum O'Gara in storage. Ann Res Rev Biol 31 (1): DOI: $10.9734 / \mathrm{arrb} / 2019 / \mathrm{v} 31 \mathrm{i} 130034$

Amadioha AC, Enyiukwu DN. 2019. Alterations of biochemical composition of leaf and stem of cowpea (Vigna unguiculata L. Walp.) by Colletotrichum destructivum O'Gara in Nigeria. J Exp Agric Intl 33 (2): DOI: 10.109734/IJEAI/2019/v33i230138.

Amadioha AC, Kenkwo PC, Markson AA. 2019. Fungitoxic potentials of extracts of plant origin against fungal rot pathogens of cassava (Manihot esculenta Crantz) in storage. Ann Res Rev Biol 31 (1): DOI: $10.9734 / \mathrm{arrb} / 2019 / \mathrm{v} 31 \mathrm{i} 130036$.

Amadioha AC. 2003. Evaluation of some plant leaf extracts against Colletotrichum lindemuthianum in cowpea. Acta Phytopathologica et Entomologica Hungarica 38: 259-265.

Amienyo CA, Ataga AE. 2007. Use of indigenous plant extracts for the protection of mechanically injured sweet potato (Ipomea batatas (L.) tubers. Sci Res Essays 2 (5): 167-170.

Asawalam EF, Emosairue SO. 2006. Comparative efficacy of Piper guineense (Schumm. Thonn.) and primophos-methyl as poisons against Sitophilis zeamais (Motsch). E-J Environ Agric Food Chem 5 (5): 1536-1545

Awurum AN, Enyiukwu DN. 2013. Evaluation of the seed-dressing potentials of phytochemicals from Carica papaya and Piper guineense on the germination of cowpea (Vigna unguiculata L. Walp.) seeds and incidence of the seed-borne fungi. Continental $\mathrm{J}$ Agric Sci 7 (1): 29-37.

Awurum AN, Amadioha AC, Emechebe AM. 2001. Effect of cropping systems on disease development in cowpea in Umudike, Southeast Nigeria. J Sustain Agric Environ 3 (1): 31-38.

Axe Anonymous. 2017. Fight acne and infections with lauric (dodecanoic) acid. www.draxe.com [April 2, 2017].

Begum JMAJ, Venudevan B, Jayanthi M. 2013. Storage fungi in groundnut and the associated seed quality deterioration-A review. Plant Pathol J 12 (3):127-134

Begum MM, Saviah M, Puteh AB, Abidim MAZ. 2007. Detection of seed-borne fungi and site of infection by Colletotrichum truncatum in naturally infected soybean. J Agric Res 2 (9): 812-819.

British Medical Association (BMA) 1992. Guide to Pesticide Chemical and Health. Edward Press Inc., London, UK.

Campos-Vegas R, Loarca-Pina G, Oomah BD. 2010. Minor components of pulses and their potential impacts on human health. Food Res Intl 43: 461-482.

Chikwendu JN, Igbatim AC, Obizoba IC. 2014. Chemical composition of processed cowpea tender leaves and husks. Intl J Sci Res Publ 4 (5): $1-5$.

COC (Coconut Oil Central) Anonymous 2017. Lauric (dodecanoic) acid the mightiest antibacterial fatty acid known to man. www.coconut-oilcentral.com, [April 2, 2017].

Costa da Silva, A, Estevao de Souza P, Amaral DC, Zeviani WM, Pinto J.EBP. 2014. Essential oils from Hyptis marrubioides, Aloysia 
gratissima and Cordia verbenacea reduce the progress of Asian soybean rust. Acta Scientarum Agronomica 36 (2): 150-166.

Costa da Silva A, Estevao de Souza, P, Da Cruz S, Machada, J, Da Silva BM, Pinto JE.BP. 2012. Effectiveness of essential oils in the treatment of Colletotrichum truncatum-infected soybean seed. Trop Plant Pathol 37 (5): 305-313.

Damm U, O'Cornell RJ, Groenevald JR, Crous PW. 2014. Colletotrichum species complex, hemibiotrophic pathogens of forage and field crops. Stud Mycol 79: 31-84.

Duru CM, Anyadoh-Nwadike SO, Okechukwu RI. 2015. Antimicrobial activity and phytochemical analysis of aqueous and ethanolic extracts of the bark of Tabernaemontana pachysiphon Stapf. Sci J Public Health 3 (1-5): 8-13.

Enyiukwu DN. 2017. Effects of extracts of some medicinal plants on Colletotrichum destructivum O'Gara causing anthracnose disease of cowpea (Vigna unguiculata L. Walp.) in Nigeria. [Dissertation] Michael Okpara University Agriculture Umudike, Nigeria.

Enyiukwu DN, Amadioha AC, Ononuju CC. 2018. Biochemical composition, potential food and feed values of aerial parts of cowpea (Vigna unguiculata L. Walp.) Greener Trends Food Sci Nutr 1 (1): 11-18.

Enyiukwu DN, Amadioha AC, Ononuju CC. 2018. Significance of cowpea leaves for human consumption. Greener Trends Food Sci Nutr 1 (1): 1-10.

Enyiukwu DN, Awurum AN, Ononuju CC, Nwaneri JA. 2014 Significance of characterization of secondary metabolites from higher plants in plant disease management. Intl J Advance Agric Res 2 (2): 30-46

Enyiukwu DN, Awurum AN. 2013. Fungitoxic effects of Carica papaya and Piper guineense extracts on Colletotrichum destructivum in the glasshouse. Continental J Agric Sci 7 (1): 23-28.

Enyiukwu DN, Awurum AN. 2012. Comparative fungitoxicity of benomyl and extracts of Carica papaya roots and seeds and Piper guineense seeds on Colletotrichum destructivum O'Gara. Continental J Biol Sci 5 (1): 26-31.

Enyiukwu DN. 2019. Nature's Pharmacy Vol. 1: A Focus on Carica papaya L. Greener Scholarly Publications (GSP), Lagos Nigeria.

Enyiukwu DN, Awurum AN. 2011. Effects of phytochemicals from Carica papaya roots and seeds and Piper guineense seeds on germination of spores of Colletotrichum destructivum O'Gara. Continental J Biol Sci 4 (2): 55-59.

Igbatim CA, Chikwendu JN, Obizoba IC. 2014. Chemical and organoleptic potentials of soups based on cowpea leaves and husks. IOSR J Environ Sci Toxicol Food Technol 8 (11): 11-22.
IMI. 1995. Description of Pathogenic fungi and Bacteria Nos. 316-317. International Mycological Institute), Kew, UK.

Mgbeahuruike EE, Yrjonen T, Vourela H, Holm Y. 2017. Bioactive compounds from medicinal plants: focus on Piper species. South Afr J Bot 112: 54-59.

Mgbeahuruike EE, Holm Y. Vourela H, Amandikwa C, Fyrquist P. 2018. An ethnobotanical survey and antifungal activity of Piper guineense used for the treatment of fungal infections in west African traditional medicine. J Ethnopharmacol 229: 157-166.

Mukherjee SK, Islam MR, Shahid SB. 2011. Efficacy of some plant extracts on the mycelia growth of Colletotrichum gloeosporioides. $\mathrm{J}$ Bangladesh Agric Univ 9 (1): 43-47.

Nakatsuji T, Kao MC, Fang JY, Zouboulis CC, Zhang L, Gallo RL, Chung-Mung H. 2009. Antimicrobial property of lauric acid against Propionibacterium acnes: its therapeutic potentials against inflammatory Acne vulgaris. J Invest Dermatol 129 (10): 2480-2488.

Naz R, Bano A. 2013. Phytochemical screening, antioxidants and antimicrobial potential of Lantana camara in different solvents. Asian J Tropical Med 1808 (13): 60104-60108.

Nielsen SS, Ohler TA, Mitchell M.C. 1997. Cowpea leaves for human consumption: production, utilization and nutrient composition. In: Singh BB (eds.). Advances in Cowpea Research, Ibadan.

Nwaogu AG Wokocha RC (2018). Effects of extracts of some botanicals against three species of fungi isolated from cocoa (Theobroma cacao) pods. Greener J Med Plants 1 (1): 001-007.

Ogu GE, Owoeye AE. 2013. In vitro control of anthracnose disease of cowpea (Vigna unguiculata L. Walp.) caused by Colletotrichum destructivum O'Gara with Cyathula prostrata L. and Diodia scandens SW leaf extracts. J Intl EthnoPharm 2 (1): 29-36.

Omotosho AE, Oluwafemi EO Maikailu S. 2014. Phytochemical analysis of Cnidoscolus aconitifolius (Euphobeaceae) leaf with spectrometric techniques. Nigerian J Pharm Appl Res 3 (1): 009-014.

Podila GK, Rogers LM, kolattukudy P. 1993. Chemical signals from avocado surface wax trigger germination and appressorium formation in Colletotrichum gloeosporioides. Plant Physiol 103 (1): 267-272. DOI: $10.1104 / p p .103 .1 .267$.

Rajeswari G, Murugan M, Moghan VR. 2012. GC-MS analysis of bioactive components of Hugonia mystax L. (Linaceae). Res J Pharm Biol Clin Sci 3 (4): 301-308.

Shen S, Goodwin P, Hsiang T. 2001. Hemibiotrophic infection and identity of the fungus Colletotrichum destructivum causing anthracnose of tobacco. Mycol Res 105 (11): 1340-1347.

Suleiman MN Emua SA. 2009. Efficacy of four plant extracts in the control of root rot disease of cowpea. Afr J Biotechnol 8 (16): 38063808 . 